\title{
Folate Deficiency Enhances Delayed Neuronal Death in the Hippocampus After Transient Cerebral Ischemia
}

\author{
Jun Hyun Yoo \\ Department of Family Medicine, Samsung Medical Center, Samsung \\ Biomedical Research Institute, Sungkyunkwan University School of Medicine, Seoul, \\ Republic of Korea
}

\section{Introduction}

Transient cerebral ischemia, in which the brain is temporarily deprived of nutrients and oxygen, results in delayed degeneration of vulnerable neurons within the CA1 region of the hippocampus. The pathophysiology of cerebral ischemic disease is a complex series of cellular biochemical process that involves intracellular ATP depletion, excitotoxicity, oxidative stress, microvascular injury, hypercoagulable hemostatic activation, post-ischemic inflammation and final cell death of neuronal, glial, and endothelial cells (Brouns et al, 2009; Jin et al, 2010).

Folate is an essential micronutrient as a methyl donor for the DNA nucleotides synthesis and cytosine methylation for the control of gene expression. Clinically, folate deficiency is linked to megaloblastic anemia and atherothrobotic vascular disease. On the biochemical basis, folate deficiency increases nuclear DNA damage via uracil misincorporation and which induces chromosome breaks (Blount et al, 1997; Fenech, 2010). A metabolic consequence of folate deficiency is the accumulation of intermediate metabolite, homocysteine. Dietary folate deficiency has been shown to decrease mitochondrial folate concentration and mitochondrial DNA content and increase mitochondrial DNA deletion in brain, leading to leakage of ROS and increase of oxidative stress (Chang et al, 2007; Ho et al, 2003; Crott et al, 2005). Electron microscopic finding showed mitochondrial degeneration in the endothelium and perivascular fibrosis in microvascular wall in the rat brain (Kim et al, 2002).

Homocysteine is a toxic amino acid to neuronal and vascular endothelial cells. Numerous epidemiological studies have recognized the association of folate deficiency and hyperhomocysteinemia with increased risk of vascular disease and ischemic stroke (Yoo et al, 1998, 2000, Kang et al, 1992). Hyperhomocysteinemia produces complex alterations in the blood vessels including oxidative stress, endothelial dysfunction and inflammatory response via the activation of transcription factor such as nuclear factor-kB (NF-kB) or activiator protein-1(AP-1). Homocysteiene upregulate E-selectin, P-selectin, ICAM-1, V-CAM-1, MCP-1 via activation of NF-kB, and AP-1 (Hwang et al, 2008; Woo et al, 2008).

No study has yet evaluated the morphological characteristics of the folate-deficient hippocampus after transient forebrain ischemia. This study examined the delayed neuronal 
death and morphologic changes in the hippocampal CA1 region after transient forebrain ischemia in a gerbil model.

\section{Materials and methods}

\subsection{Experimental animals, diets, measurements of body weight and serum homocysteine level}

For a detailed description of the present experimental method is referred to the published article (Hwang IK et al, 2008). The animals were fed with the respective diet ad libitum for 3 months. After 3 months on the folate deficient-diets (FAD), blood was taken for analysis of homocysteine levels. Homocysteine levels in serum samples were quantified with the use of an high performance liquid chromatography(Yoo et al, 1998).

\subsection{Induction of transient forebrain ischemia and tissue processing for histology}

After 3 months of folate deficient-diet, animals were anesthetized with isoflurane in $33 \%$ oxygen and $67 \%$ nitrous oxide. Bilateral common carotid arteries were isolated and occluded using non-traumatic aneurysm clips. After 5 min of occlusion, the aneurysm clips were removed from the common carotid arteries. The body temperature under freeregulating or normothermic $\left(37 \pm 0.5^{\circ} \mathrm{C}\right)$ conditions was monitored with a rectal temperature probe and maintained during and after the surgery until the complete recovery from anesthesia. Thereafter, animals were kept on the thermal incubator to maintain the body temperature of animals until the euthanasia. Sham-operated animals served as controls: these sham-operated animals were subjected to the same surgical procedures except no occlusion of common carotid artery.

For the tissue preparation, sham- and ischemia-operated animals were anesthetized and perfused transcardially with $0.1 \mathrm{M}$ phosphate-buffered saline ( $\mathrm{pH} 7.4$ ) followed by $4 \%$ paraformaldehyde in $0.1 \mathrm{M}$ phosphate-buffer ( $\mathrm{pH}$ 7.4). The brains were removed and postfixed in the same fixative for 6 hours. The brain tissues were cryoprotected by infiltration with $30 \%$ sucrose overnight.

\subsection{Examination of neuronal damage: Cresyl violet staining}

The sections in the hippocampal CA1 region were mounted on gelatin-coated microscopy slides. Cresyl violet acetate (Sigma) was dissolved at $1.0 \%(w / v)$ in distilled water, and glacial acetic acid was added to this solution. The sections were stained and dehydrated by immersing in serial ethanol baths, and they were then mounted with Canada balsam (Kanto Chemical, Tokyo, Japan). All animals ( $n=7$ at each time) were sampled according to the time lines to evaluate the evolving histopathologic changes ( 3 hour, 12 hour, 1 day, 2day, 3day, 4day after reperfusion).

\subsection{Examination of neuronal damage: NeuN immunohistochemistry}

The sections in the hippocampal CA1 region were sequentially treated with $0.3 \%$ hydrogen peroxide in PBS for $30 \mathrm{~min}$ and 10\% goat serum in $0.05 \mathrm{M}$ PBS for $30 \mathrm{~min}$. The sections were next incubated with diluted mouse anti-NeuN (diluted 1:1,000, Chemicon International, Temecula, CA) overnight at room temperature. Thereafter the tissues were exposed to biotinylated goat anti-mouse IgG and streptavidin peroxidase complex (Vector, Burlingame, $\mathrm{CA})$. And they were visualized with 3,3'-diaminobenzidine in $0.1 \mathrm{M}$ Tris- $\mathrm{HCl}$ buffer and 
mounted on the gelatin-coated slides. After dehydration the sections were mounted in Canada Balsam (Kanto Chemical).

\subsection{Examination of neuronal apoptosis: TUNEL staining}

The sections in the hippocampal CA1 region were stained using terminal deoxynucleotidyl transferase dUTP-biotin nick-end-labeling (TUNEL) staining. The sections were washed in 0.1 M PBS (pH 7.4) for 30 min before being incubated in blocking solution $\left(3 \% \mathrm{H}_{2} \mathrm{O}_{2}\right.$ in $0.01 \mathrm{M}$ PBS) at room temperature for $20 \mathrm{~min}$, and were then washed in PBS for $5 \mathrm{~min}$ and treated with permeabilization solution ( $0.1 \%$ Triton X-100 in $0.1 \%$ sodium citrate) at $4^{\circ} \mathrm{C}$ for $2 \mathrm{~min}$. Next, the sections were washed 3 times, and then incubated in TUNEL reaction mixture according to kit instructions (Roche Molecular Biochemicals, Mannheim, Germany). The TUNEL reaction mixture was prepared with a 1:2 dilution of the enzyme solution. The sections were washed 3 times with PBS (10 min per wash) before being incubated in converter-POD (Roche Molecular Biochemicals) at $37^{\circ} \mathrm{C}$ for $30 \mathrm{~min}$ and treated with $\mathrm{DAB}$-substrate solution for 1.5-2 min. After washing the sections 3 times, the sections were counterstained with methyl green, dehydrated and coverslipped with Canada Balsam (Kanto Chemical).

\subsection{Examination of neuronal damage: Fluoro-Jade B (F-J B) histofluorescence staining}

According to the experiment of Candelario-Jalil et al (2003), the sections were first immersed in a solution containing $1 \%$ sodium hydroxide in $80 \%$ alcohol, and followed in $70 \%$ alcohol. They were then transferred to a solution of $0.06 \%$ potassium permanganate, and transferred to a $0.0004 \%$ F-J B (Histochem, Jefferson, AR) staining solution. After washing, the sections were placed on a slide warmer (approximately $50^{\circ} \mathrm{C}$ ), and then examined using an epifluorescent microscope (Carl Zeiss, Göttingen, Germany) with blue (450-490 nm) excitation light and a barrier filter (Schmued and Hopkins, 2000).

\subsection{Immunohistochemistry for 8-hydroxy-2'-deoxyguanosine (8-OHdG)}

At designated times ( $30 \mathrm{~min}, 3 \mathrm{~h}, 6 \mathrm{~h}, 12 \mathrm{~h}, 24 \mathrm{~h}, 2$ days, 3 days and 4 days) after the surgery, sham- and ischemia-operated animals ( $n=7$ at each time point) were used for this experiment. To obtain the exact data in this study, tissues of sham-operated and operated animals were processed under the same conditions. The sections were sequentially treated with $0.3 \%$ hydrogen peroxide in PBS for $30 \mathrm{~min}, 150 \mu \mathrm{M} / \mathrm{ml}$ RNase A for $1 \mathrm{~h}$ at $37^{\circ} \mathrm{C}, 50 \mathrm{mM}$ sodium hydroxide in $40 \%$ ethanol for $10 \mathrm{~min}$. The sections were incubated with mouse anti8-OHdG antiserum (1:100) (Bail et al., 1996; Won et al., 1999, 2001) in PBS containing 0.3\% Triton X-100 and 2\% normal goat serum overnight at room temperature. After washing 3 times for $10 \mathrm{~min}$ with PBS, the sections were incubated sequentially, in goat anti-mouse IgG and Vectastain (Vector), diluted 1:200 in the same solution as the primary antiserum. Between incubations, the tissues were washed with PBS 3 times for $10 \mathrm{~min}$ each. The sections were visualized using 3,3'-diaminobenzidine tetrachloride (Sigma) in $0.1 \mathrm{M}$ Trisbuffer and mounted on gelatin-coated slides.

\subsection{Platelet endothelial cell adhesion molecule-1 (PECAM-1) staining}

Immunohistochemistry for PECAM-1 (final mediator of neutrophil transendothelial migration) was conducted according to the method by Hwang et al (2005b). In brief, the sections were sequentially treated with $0.3 \%$ hydrogen peroxide $\left(\mathrm{H}_{2} \mathrm{O}_{2}\right)$ in PBS and $10 \%$ 
normal horse serum in $0.05 \mathrm{M}$ PBS. The sections were next incubated with diluted mouse anti-PECAM-1 antibody (diluted 1:1000, Santa Cruz Biotechnology, Santa Cruz, CA) overnight. Thereafter, the tissues were exposed to biotinylated horse anti-mouse IgG and streptavidin-peroxidase complex (Vector). The sections were visualized with DAB in $0.1 \mathrm{M}$ Tris- $\mathrm{HCl}$ buffer and mounted on the gelatin-coated slides.

\subsection{Immunohistochemistry for glial fibrillary acidic protein (GFAP) and ionized calcium-binding adapter molecule 1 (lba-1)}

In order to examine the degree of reactive gliosis in the CA1 region in the CD- and FADtreated groups after ischemia/reperfusion, we carried out immunohistochemical staining with rabbit anti-GFAP (diluted 1:1,000, Chemicon) for astrocytes and rabbit anti-Iba-1 (diluted 1:500, Wako, Osaka, Japan) for microglia according to the above mentioned-method (see the NeuN immunohistochemistry). The tissues were exposed to biotinylated goat antirabbit IgG (diluted 1:200; Vector) and streptavidin peroxidase complex (diluted 1:200; Vector). And they were visualized with $\mathrm{DAB}$ in $0.1 \mathrm{M}$ Tris- $\mathrm{HCl}$ buffer and mounted on the gelatin-coated slides. After dehydration the sections were mounted in Canada Balsam (Kanto Chemical).

\subsection{Quantification of data}

All measurements were performed in order to ensure objectivity in blind conditions, by two observers for each experiment, carrying out the measures of control and experimental samples under the same conditions.

The number of survived pyramidal cells in the stratum pyramidale within the CA1 region was counted using an AxioM1 light microscope (Carl Zeiss) photomicroscope at a magnification of $400 \times$. Histologic analysis was performed by a blinded observer and the average of the right and left survived cell numbers (neurons per $1 \mathrm{~mm}$ liner length) in a single section of the dorsal hippocampal CA1 region was calculated as reported by Kirino group (1986). Five sections of cresyl violet/NeuN and TUNEL/F-J B staining from each animal were used for counting.

Fifteen sections from a animal were randomly selected from the corresponding areas of the hippocampus in order to quantitatively analyze 8-OHdG, GFAP, Iba-1 and PECAM-1 immunoreactivity in the hippocampal CA1 region. The mid-point areas of the hippocampal CA1 region were measured on the monitor at a magnification of 25-50x. Images of all 8-OHdG, GFAP, Iba-1 and PECAM-1 immunoreactive structures taken from 3 layers (strata oriens, pyramidale and radiatum in the hippocampus proper, and molecular, granule cell and polymorphic layers in the dentate gyrus) were obtained through light microscope (Carl Zeiss, Germany). The staining intensity of all 8-OHdG, GFAP, Iba-1 and PECAM-1 immunoreactive structures was evaluated on the basis of a optical density (OD).

\section{Results}

3.1 Folate deficient change of body weight and serum concentration of homocysteine Folate deficiency rendered the FAD-(folate deficient-diet) group susceptible to ischemia/reperfusion. After 3 months on the folate deficient-diets, serum levels of 
homocysteine were determined and found to be 5- to 8-fold higher in gerbils subjected to FAD compared to CD-(control diet) group. The body weight gain during the first diet month was significantly lower in the FAD group than in the CD group, this was consistent throughtout the 3 months of observation.

\subsection{Neuronal damage}

Cresyl violet and NeuN stainings show the positive pyramidal neurons on the first day. The cell densities decreased over the time after ischemia/reperfusion. Two days after ischemia/reperfusion, neurodegeneration were found in the neurons in the FAD-group (Figs. 1F, 1N), when no significant changes were seen in the CD-group (Figs. 1B, 1J). In FADgroup, CA1 pyramidal neurons showed cytoplasmic shrinkage and chromatic condensation. Starting from day three after ischemia/reperfusion, pyramidal neurons in FAD-group showed delayed neuronal death, which became morphologically similar to that of day four in CD-group (Figs. 1D, 1G, 1K and 1O).

Delayed neuronal death in the CA1 region was identified using TUNEL or F-J B staining. CA1 pyramidal neurons in the CD- and FAD-groups 1 day after ischemia/reperfusion did not show TUNEL or F-J B staining (Figs. 2B, 2F, 2J, 2N). Two days after ischemia/reperfusion, pyramidal neurons in the FAD-group showed TUNEL or F-J B staining representing neurodegeneration (Figs. 2G, 2O). Four days after ischemia/ reperfusion, pyramidal neurons in the CD-group showed TUNEL or F-J B staining (Figs. 2D, 2L), but TUNEL or F-J B stained pyramidal neurons decreased in FAD-group (Figs. 2H, 2P). These shows that folate deficiency enhances delayed neuronal death in the hippocampus after transient cerebral ischemia

\subsection{Change in 8-hydroxy-deoxyguanosine immunoreactivity}

In this study, we found a significant difference in 8- hydroxy-deoxyguanosine immunoreactivity between the CD- and FAD-groups after ischemia/reperfusion (Figs. 3, 4). In both the sham-operated groups, very weak 8- hydroxy-deoxyguanosine immunoreactivity was detected in the CA1 region (Figs. 3A, 3E). The oxidative change in both groups began to increase at $30 \mathrm{~min}$ after ischemia/reperfusion, which the peak changes were noted at 12 hour after ischemia/reperfusion (Figs. 3C, 3G, Fig 4). At 12 hour after ischemia, 8- hydroxy-deoxyguanosine immunoreactivity in FAD-group was much higher than that in CD-group (Fig. 4). Thereafter, it decreased with time (Figs. 3D and 4). Four days after ischemic insult, 8-OHdG immunoreactivity in both groups was lower than that in the sham-operated groups (Fig. 4).

\subsection{Change in PECAM-1 immunoreactivity}

PECAM-1 immunoreactivity in microvessels in the hippocampal CA1 region changed after ischemia/reperfusion (Figs. 5, 6). In the CD- and FAD-fed-sham-operated groups, microvessels showed weak PECAM-1 immunoreactivity (Fig. 5A, 5B), and this immunoreactivity increased with time after ischemic insult in both of these groups (Figs. 5C5 H, Fig 6). PECAM-1 immunoreactivity in CA1 in both groups increased significantly 3 days after ischemia/reperfusion (Figs. 5G, 5H, Fig 6) and PECAM-1 immunoreactivity in FADgroup was much higher than that in $\mathrm{CD}$-group (Fig. 6). 

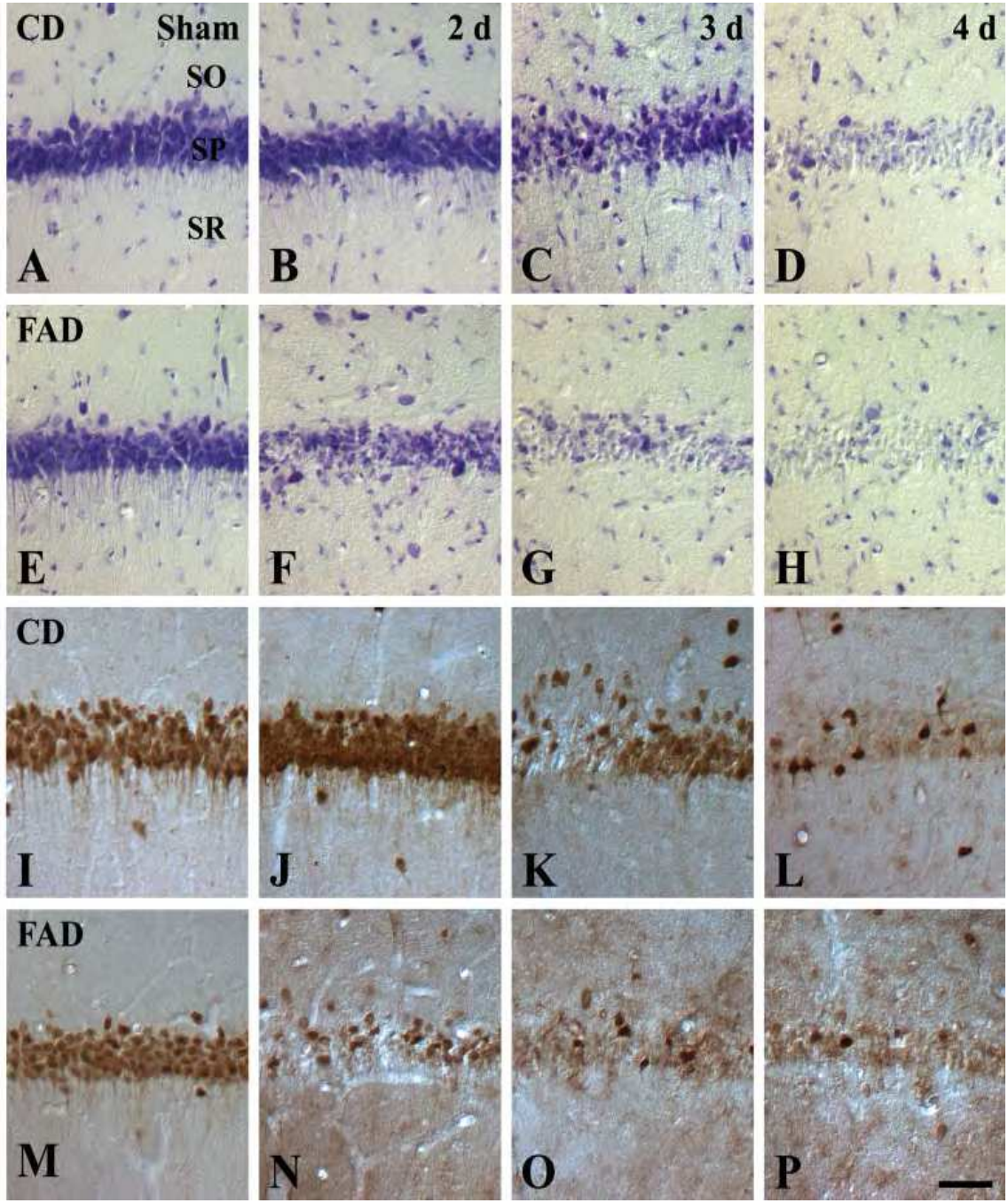

Fig. 1. Cresyl violet $(\mathrm{CV})$ and NeuN staining of the CA1 region in sham-operated $(\mathrm{A}, \mathrm{E}, \mathrm{I}, \mathrm{M})$ and ischemia-operated groups 2 days $(\mathrm{B}, \mathrm{F}, \mathrm{J}, \mathrm{N}), 3$ days $(\mathrm{C}, \mathrm{G}, \mathrm{K}, \mathrm{O})$ and 4 days $(\mathrm{D}, \mathrm{H}, \mathrm{L}, \mathrm{P})$ after ischemia/reperfusion and feeding with a folic acid-deficient or control diet. Two days after ischemia/reperfusion, CV- or NeuN-positive pyramidal neurons in the folate-deficient diettreated group show cytoplasmic shrinkage and chromatic condensation. Three days after ischemia/reperfusion, CV- or NeuN-positive pyramidal neurons in the folate-deficient diettreated group show "delayed neuronal death" like that in the control diet-treated group 4 days after ischemia/reperfusion. SO, stratum oriens; SP, stratum pyramidale; SR,stratum radiatum. 


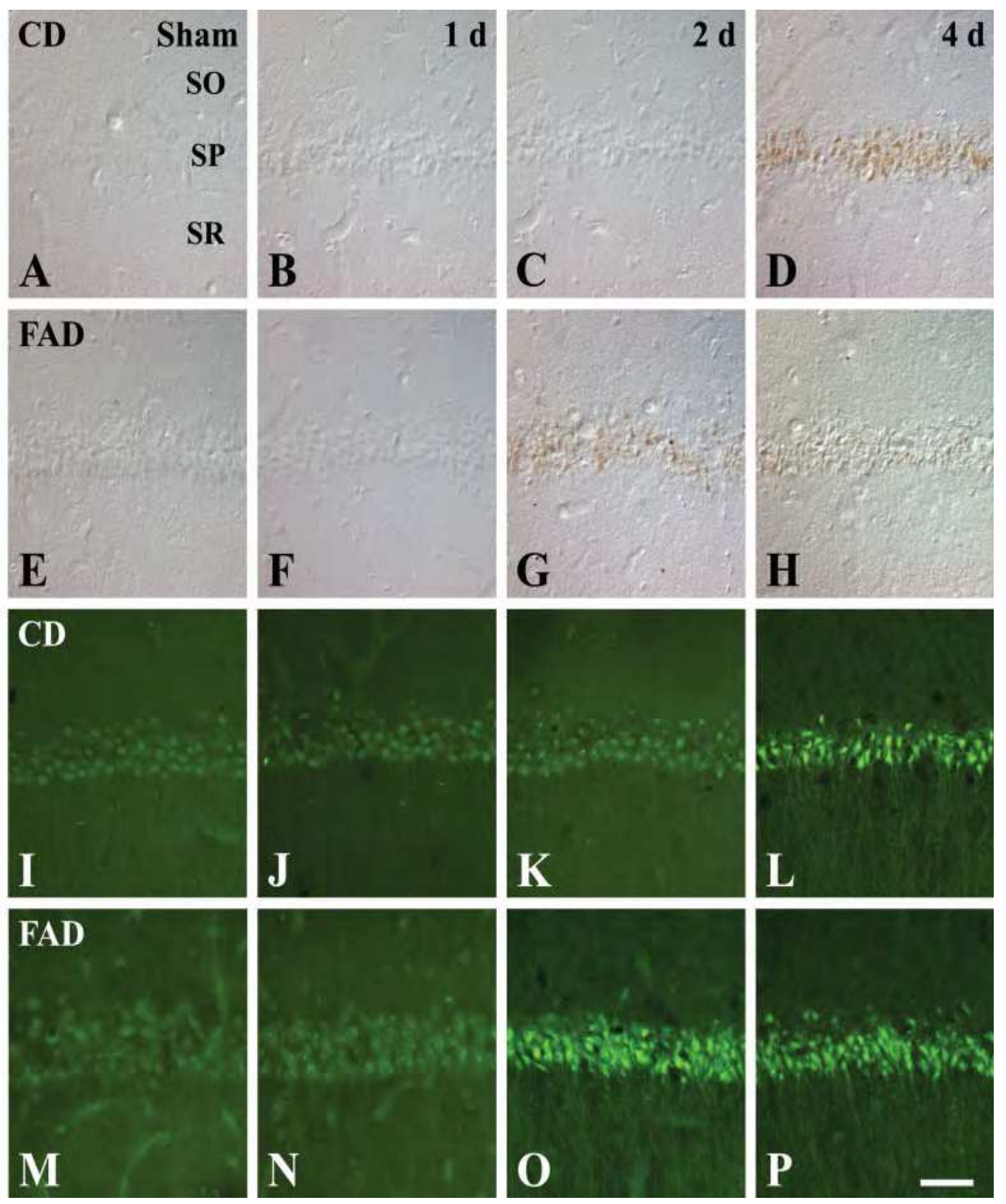

Fig. 2. TUNEL and Fluoro-Jade B (F-JB) staining of the CA1 region in the sham-operated $(\mathrm{A}, \mathrm{E}, \mathrm{I}, \mathrm{M})$ and ischemia-operated groups 1 days $(\mathrm{B}, \mathrm{F}, \mathrm{J}, \mathrm{N}), 2$ days $(\mathrm{C}, \mathrm{G}, \mathrm{K}, \mathrm{O})$, and 4 days $(\mathrm{D}, \mathrm{H}, \mathrm{L}, \mathrm{P})$ after ischemia/reperfusion and feeding with a folic acid-deficient or control diet. Two days after ischemia/reperfusion, TUNEL- or F-JBpositive pyramidal neurons are observed in stratum pyramidale (SP) of the folate-deficient diet-treated group. Four days after ischemia-reperfusion, TUNEL or F-JB reaction decreases in pyramidal neurons in the SP of the folate-deficient diet-treated group. SO, stratum oriens; SR, stratum radiatum. 

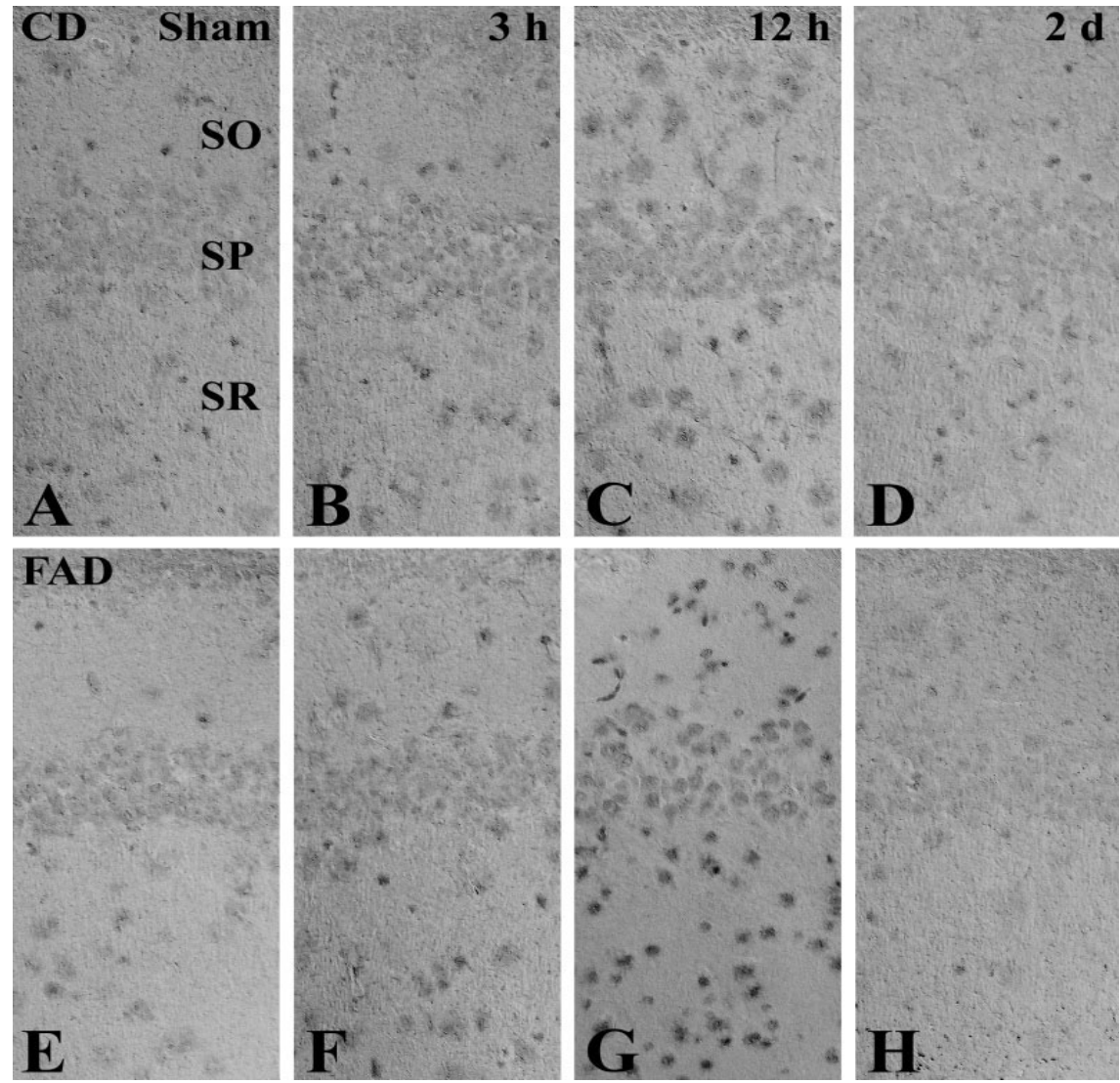

Fig. 3. Immunohistochemistry for 8-hydroxy-deoxyguanosine in the CA1 region in the control diet- and folate deficient diet-sham $(\mathrm{A}, \mathrm{E})$ and ischemia-operated groups at $3 \mathrm{hr}(\mathrm{B}, \mathrm{F})$, $12 \mathrm{hr}(\mathrm{C}, \mathrm{G})$, and 2 days $(\mathrm{D}, \mathrm{H})$ after ischemia/reperfusion. At $12 \mathrm{hr}$ after ischemic insult, 8 - hydroxy-deoxyguanosine immunoreactivity in both groups is highest in CA1 $(C, G)$, showing more dense immunoreactivity in folate-deficient diet- than in the control dietgroup. Two days after ischemia/reperfusion, 8 - hydroxy-deoxyguanosine immunoreactivity in folate-deficient diet-group is much lower than that in control diet-group $(\mathrm{D}, \mathrm{H})$. $\mathrm{SP}$, stratum pyramidale; $\mathrm{SO}$, stratum oriens; $\mathrm{SR}$, stratum radiatum. 


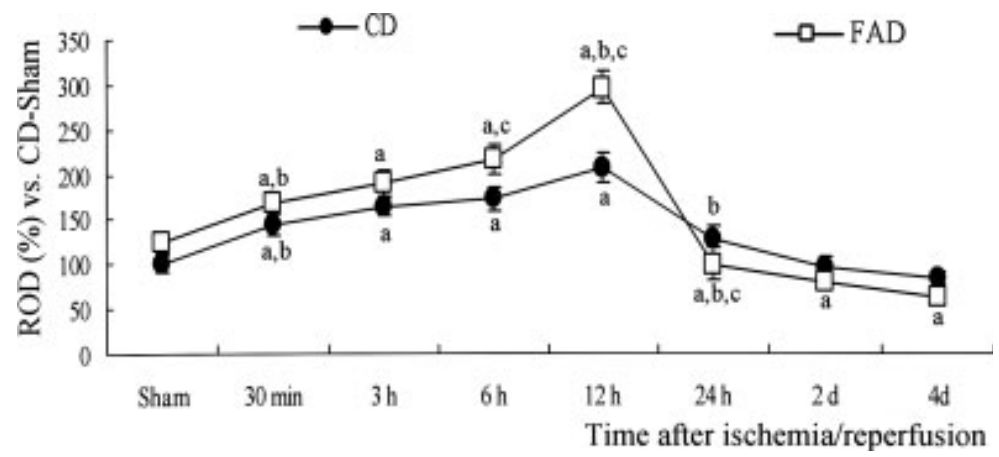

Fig. 4. Relative optical density (ROD) as percentage of 8-hydroxy-deoxyguanosine immunoreactivity in the CA1 region after transient ischemia $(n=5-7$ per group; $\mathrm{aP}<0.05$ significantly different from the control diet- or folate-deficient diet-fed sham-operated group, $\mathrm{bP}<0.05$ significantly different from the control diet- or folate-deficient diet-treated preadjacent group, $\mathrm{cP}<0.05$ between the control diet- and the folate deficient diet-groups). Bars indicate means \pm SEM.
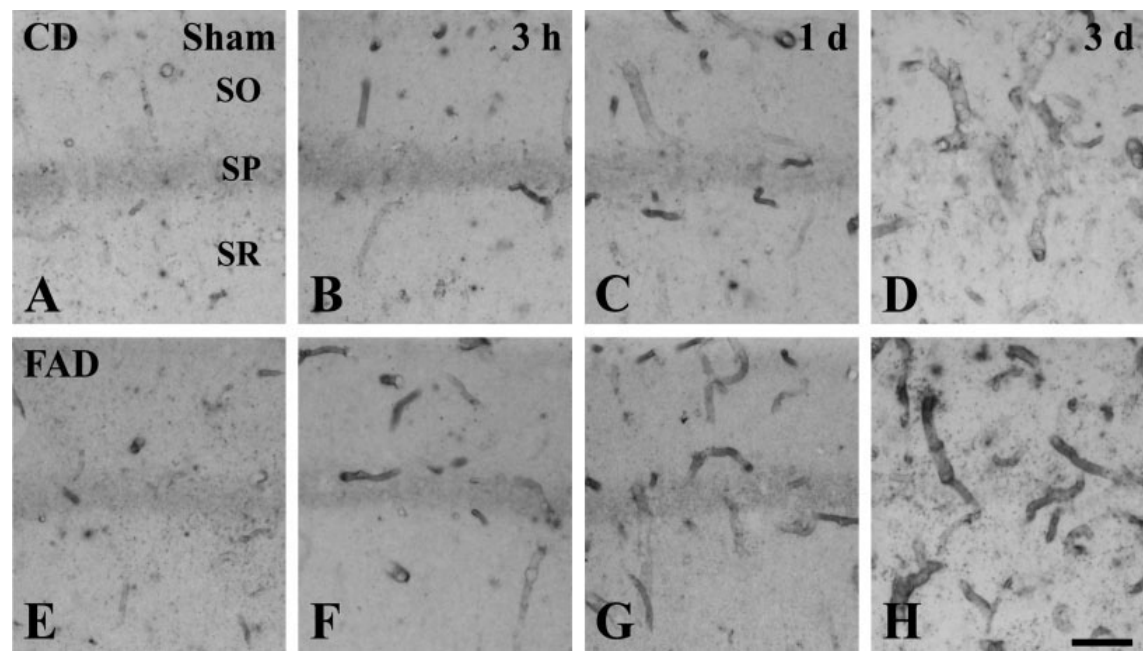

Fig. 5. Immunohistochemistry for platelet endothelial cell adhesion molecule-1 (PECAM-1) in the $\mathrm{CA} 1$ region in sham-operated $(\mathrm{A}, \mathrm{E})$ and in ischemia-operated groups at $3 \mathrm{hr}(\mathrm{B}, \mathrm{F})$, 1 day $(C, G)$, and 3 days $(D, H)$ after ischemia/reperfusion in control diet- and folate-deficient diet-groups. In control diet-(A) and folate-deficient diet -sham-operated (E) groups, weak PECAM-1 immunoreactivity is detected in microvessels. Three days after ischemia / reperfusion, PECAM-1 immunoreactivity in both groups increased significantly $(\mathrm{G}, \mathrm{H})$; the immunoreactivity in folate deficient diet-group is higher than that in control diet-group. $\mathrm{SP}$, stratum pyramidale; $\mathrm{SO}$, stratum oriens; $\mathrm{SR}$, stratum radiatum. 


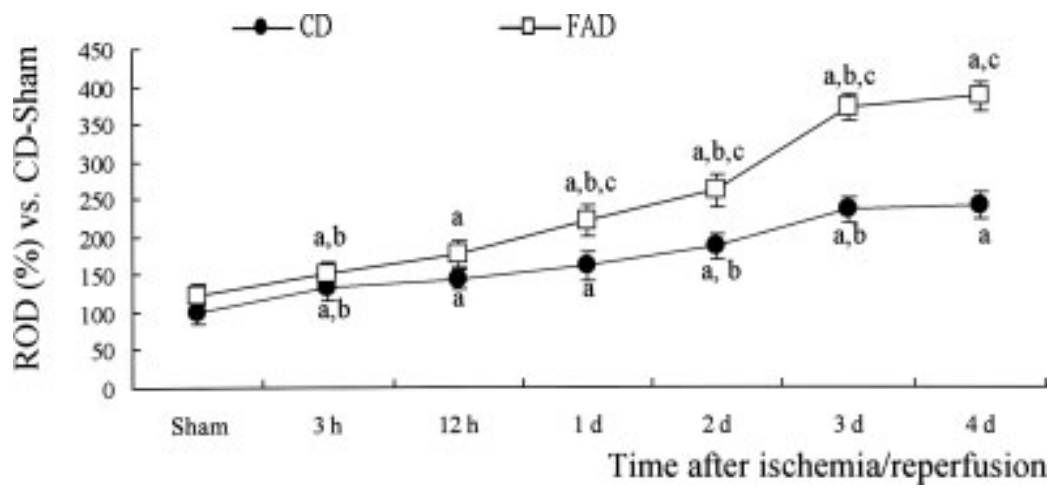

Fig. 6. Relative optical density (ROD) as percentage of PECAM-1 immunoreactivity in the CA1 region after transient ischemia (n 57 per group; $\mathrm{aP}<0.05$ significantly different from the control diet- or folate deficient diet treated sham-operated group, $\mathrm{bP}<0.05$ significantly different from the $\mathrm{CD}$ - or folate-deficient diet-treated preadjacent group, $\mathrm{cP}<0.05$ between the control diet- and the folate-deficient diet-treated groups). Bars indicate means $\pm \mathrm{SEM}$.

\subsection{Reactive gliosis}

Significant morphological changes were observed in glial cells in the CA1 region in the CDand FAD-groups after ischemia/reperfusion. This change began 2 days after ischemia/reperfusion (Figs. 7).

Astrocytes. In the FAD-sham-operated group, weak GFAP immunoreactivity was detected in the CA1 region as in the CD-group (Fig. 7A, 7E). GFAP immunoreactive astrocytes had thin processes. Two days after ischemia/reperfusion, many astrocytes showed morphological changes in both groups (Fig. 7B, 7F), although at this time many more astrocytes in the FAD-treated group showed hypertrophied processes. Three days after ischemia/reperfusion, GFAP immunoreactive astrocytes in the FAD-treated group showed punctuated cytoplasm, whereas in the CD-group the cytoplasm of GFAP immunoreactive astrocytes was hypertrophied (Fig. 7C, 7G). Four days after ischemia/reperfusion, the processes of GFAP-immunoreactive astrocytes became hypertrophied, and the number and immunoreactivity in GFAP-immunoreactive astrocytes in the FAD-group were higher in the CD-group (Figs. 7D, 7H).

Microglia. Iba-1 immunoreactivity in the FAD-sham-operated group was similar to that in the CD-sham-operated group (Figs. 7I, 7M). Microglia in the CD-group were activated 2 days after ischemia/reperfusion, and many activated microglia in the FAD-group had aggregated to the stratum pyramidale, in which pyramidal neurons showed delayed neuronal death (Fig. 7J, 7N). Three days after ischemia/reperfusion, Iba-1 immunoreactive microglia in the FAD-group were concentrated in the stratum pyramidale of the CA1 region (Fig. 7O), whereas in the CD-group Iba-1 immunoreactive microglia were dispersed in CA1 (Fig. 7K). Four days after ischemia/reperfusion, microgliosis in the FAD-group was severer than in the CD-group (Figs. 7L, 7P). 

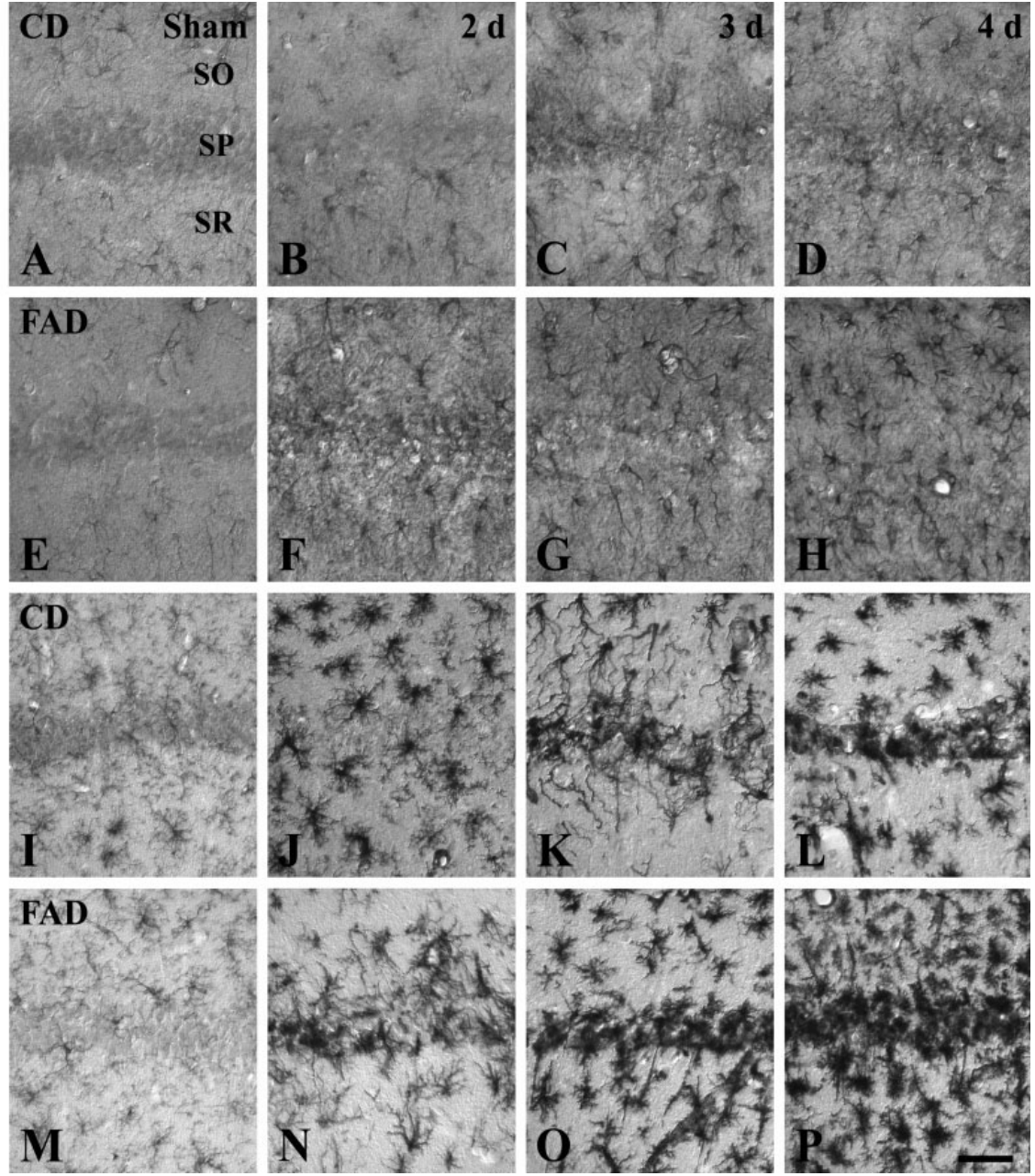

Fig. 7. Immunohistochemistry for GFAP representing astrocytes and Iba-1 representing microglia in the CA1 region in sham-operated $(\mathrm{A}, \mathrm{E}, \mathrm{I}, \mathrm{M})$ and ischemia-operated groups 2 days $(\mathrm{B}, \mathrm{F}, \mathrm{J}, \mathrm{N}), 3$ days $(\mathrm{C}, \mathrm{G}, \mathrm{K}, \mathrm{O})$, and 4 days $(\mathrm{D}, \mathrm{H}, \mathrm{L}, \mathrm{P})$ after ischemia/reperfusion and feeding with folate-deficient diet or control diet. GFAP immunoreactivity-punctuated astrocytes in folate-deficient diet-group are detected 3 days after ischemia/reperfusion, whereas, in control diet-group, they are detected 4 days after ischemia/reperfusion. An increase of Iba-1-immunoreactive microglia is noted 3 days after ischemia/reperfusion in the stratum pyramidale of folate-deficient diet -group, whereas, in control diet-group, Iba-1-immunoreactive microglia is markedly increased 4 days after ischemia/reperfusion. 


\section{Discussion}

Folate deficiency is common condition, especially in geriatric population which is caused by environmental and genetic factor. The genetic variant of methylenetetrahydrofolate reductase is very common $(10-15 \%)$. Moderate hyperhomocysteinemia $(15-30 \mu \mathrm{mol} / \mathrm{L})$ is very common condition which is linked to increased risk of artherothrombotic vascular disease (Yoo et al). Low dietary intake of folic acid is associated with increased homocysteine levels and an increased risk of heart disease and stroke (Giles et al., 1995; hankey GJ et al, 2001). Homocysteine has direct effects on the endothelium (Wall et al,1980; Kamath et al., 2006; Lominadze et al., 2006) and astrocytes (Kranich et al., 1998), which are mediate signaling between endothelium and neurons (Nedergaard et al., 2003). In addition, the treatment of folic acid with vitamin $\mathrm{B}_{12}$ and $\mathrm{B}_{6}$ improves the blood-brain barrier function in human (Lehmann et al., 2003). Among the hypoxic brain damage, most sensitive are the pyramidal neurons in the CA1 region of the hippocampus. In experimental animal, transient forebrain ischemia, which temporarily deprives the brain of glucose as well as oxygen, results in the insidious delayed degeneration of specific vulnerable neurons within the CA1 region of the hippocampus (Kirino, 1982; Pulsinelli et al., 1982).

In FAD-group, cresyl violet or NeuN positive neurons began to decrease day 2 after ischemia/reperfusion, while in CD-group, cresyl violet or NeuN positive neurons began to decrease day 3 after ischemia/reperfusion. Delayed neuronal death of CA1 pyramidal neurons in the CD-groups occurred day 4 after ischemia/reperfusion, whereas in the FADgroup, delayed neuronal death in CA1 pyramidal neurons occurred day 3 after ischemia/reperfusion. In addition, CA1 pyramidal neurons in the FAD-group showed TUNEL or F-J B staining representing neurodegeneration day 2 after ischemia/reperfusion. This is the first report that neuronal damage in the ischemic CA1 region is accelerated by folate deficiency.

\subsection{Excitotoxicity of homocysteine}

Homocysteine is easily carried into neuronal cells via a specific membrane transporter, leading to high intracellular homocysteine concentrations (Grieve et al., 1992). It has been shown that homocysteine and its metabolic derivatives activate both group I metabotropic glutamate receptors (mGluR) (Dalton et al, 1997) and NMDA receptors (Pullan et al., 1987), suggesting the role of homocysteine-induced excitotoxicity. Homocysteine can play as an endogenous glutamate receptor agonist (Lipton et al, 1997; Do et al, 1986; Ito et al, 1991) by activating on N-methyl-D-aspartate(NMDA) receptor subtype. The oxidative product of homocysteine, homocysteic acid, can functions as an excitatory neurotransmitter by activating NMDA receptor (Olney et al, 1987) The neurotoxicity of homocysteic acid in the brain can be partially abrogated by using a NMDA antagonist, suggesting a role for agonistic function (Olney et al, 1987; Kim et al, 1987).

Depending on glycine concentration, homocysteine showed dual response. In the condition of low glycine, homocysteine acts as a antagonist of the glycine site of the NMDA receptor, resulting in neuroprotective function. However, in the situation of high glycine levels after brain ischemia, homocysteine can bind and activate NMDA receptor, leading to excitotoxic damage (Lipton et al, 1997). These actions suggest that folate deficiency accompanied by hyperhomocysteinemia may contribute to the early brain damage after ischemia.

In addition, homocysteine has been reported to induce an extra-cellular signal regulated kinase in the hippocampus(Robert et al, 2005). Homocysteine also activates group I 
metabotropic glutamate receptors (mGluRl), leading to activation of protein kinase $\mathrm{C}$ and increased intracellular $\mathrm{IP}_{3}$ formation, increasing the intracellular calcium ion, especially in endoplasmic reticulum (Dalton et al, 1997).

\subsection{Homocysteine and apoptosis pathway}

Homocysteine-induced ROS generation enhances the activation of NF-kB (Chern et al., 2001). NF-kB is one of the transcriptional factors that can be controlled by the cellular redox status. NF-kB plays a role in the control of oxidative stress-mediated apoptosis. In the oxidative conditions, neuronal cell death derives from excessive calcium influx and ROS leading to excitotoxicity. In a transient middle cerebral artery occlusion experiment, increased DNA binding was detected after reperfusion following 2 hour ischemia (Schneider et al., 1999), suggesting the activation of NF-kB. Increased transcriptional activity of NF-kB has been identified in mouse models of both permanent and transient cerebral ischemia using kB-dependent $\beta$-globin reporter gene assay (Schneider et al., 1999). NF-kB target genes include proinflammatory cytokines shown to be expressed in cerebral ischemia. TNF, IL-6, inducible nitric oxide synthase, intercellular adhesion molecule 1 (ICAM-1), and matrix metallopeptidase (MMP) 9 are major players in the post-ischemic inflammation of brain (Wang et al., 2007; Gilmore, 2008). IL-1 is another possible inducer of NF-kB activity in the ischemic brain (Kunz et al., 2008). Both IL-1a and IL-1 $\beta$ are rapidly induced in cerebral ischemia (Allan et al., 2005).

\subsection{Hyperhomocysteinemia and hypercoagulable state of blood}

The mechanism by which hyperhomocysteinemia can cause the hypercoagulable state of blood and an increased risk of thrombosis has poorly established. There have been growing evidences from the various aspects. In vitro study of cultured cells showed a toxic effect of homocysteine on endothelial cell viability ( Wall, 1980). Cultured endothelial cells under high concentration of homocysteine were not viable with copper that led to the oxidation of homocysteine, concomitant with hydrogen peroxide generation (Starkebaum and Harlan, 1986). Homocysteine inhibited the synthesis of prostacyclin, a potent inhibitor of platelets in cultured cells (Wang,1993). In vitro studies have shown that high concentration of homocysteine promote blood clotting cascade. Homocysteine activated factor $\mathrm{V}$ on cultured endothelial cells (Rodgers and Kane, 1986) and inhibited protein C activation in cultured endothelial cells (Rodgers, 1990). At concentrations greater than $5 \mathrm{mmol} / \mathrm{L}$, homocysteine inhibited thrombomodulin surface expression (thrombomodulin promote activation of the anticoagulant protein C and inhibit procoagulant activity of thrombin) (Lentz , 1991). Homocysteine blocked tissue-type plasminogen activiator in endothelial cells (Hajjar, 1993). Homocysteine increased platelet adhesion (Blann, 1992), and induced tissue factor (Fryer, 1993), and suppressed anticoagulant, heparan sulfate expression (Nishinaga, 1993). It has been documented that homocysteine level as low as 8 micromol/L increased affinity of lipoprotein(a) for plasmin modified fibrin surfaces, inhibiting plasminogen activation (Harpel, 1992). In vivo studies showed an abnormally increased biosynthesis of thromboxane A2 in patients with CBS deficiency (Di Minno, 1993), and endothelial dysfunction (Lentz, 1996). It have been reported that impaired regulation of endotheliumde-rived relaxing factor \& nitrogen oxides (Stamler, 1993) and oxidation of low-density lipoprotein in vitro (Pathasarathy, 1987). Folate deficiency may contribute the development of atherothrombogenic condition. In the rat model, dietary folate deficiency, a major cause 
of hyperhomocysteinemia, was associated with 20-fold enhanced macrophage-derived tissue factor activity and increased ADP- and thrombin-induced platelet aggregation (Durand et al, 1996). In vitro endothelial cell study, cell treated with homocysteine showed a significant decrease in glutathione peroxidase transcription and activity, suggesting the impairment of endothelial ability to detoxify oxidative stress and leading to attenuation of bioavailable nitric oxide, a potent anti-thrombotic factor (Upchurch, 1997)

Recent oligo-array technology data validated by real time reverse transcriptase-polymerase chain reaction showed the changed gene expression in animal fed folate deficient diet, suffering from hyperhomocystinemia. Folate deficiency upregulate integrin beta-3, Rap1b, glycoprotein V, platelet-endothelial cell adhesion molecule-1(PECAM-1) and von Willebrand factor, leading to platelet activation and aggregation. In addition, upregulation of coagulation factor XIIIa, plasminogen activator inhibitor-1, and down regulation of tissuetype plasminogen activator were observed (Ebbesen LS et al, 2006).

\subsection{Oxidative stress and neurotoxicity in hyperhomocysteinemia and folate deficiency}

The highly reactive sulfhydryl group in the homocysteine is readily oxidized to generate reactive oxygen species (Starkebaum and Harlan, 1986), suggesting that homocysteine can cause cell injury through a mechanism involving oxidative damage. The oxidative stress has been noted that hyperhomocysteinemia and folate deficiency induces or potentiates the toxic effects on the neuronal cells in vivo or in vitro. In early study, Wall et al.(1980) showed homocysteine oxidation is related to hydrogen peroxide generation. In human neuroblastoma cells cultured in folate-deprived media, oxidative stress played a role for homocysteine toxicity in neuronal cells (Ho et al, 2003). The cytotoxicity of homocysteine was compromised by antioxidants including N-acetyl cysteine, vitamin E or C (Reis et al, 2002; Wyse et al, 2002). Antoxidants vitamin including vitamin $\mathrm{E}$ or $\mathrm{C}$ prevented memory dysfunction induced by homocysteine administration in the rats (Reis et al, 2002) and the reduction of Na-K ATPase activity caused by hyperhomocyeteinemia in rats(Wyse et al, 2002). Folate deficiency decreased the proliferating cells in the dentate gyrus of adult mice hippocampus (Kruman et al, 2005). Folate deprivation led to pronounced hyperhomocysteinemia and reactive oxygen species. Folate deficient condition increased amyloid-beta-induced apoptosis, while high level of folate supplementation abrogated the reactive oxygen species generation by amyloid-beta(Ho et al, 2003). Folate deprivation in neuroblastoma cells showed an increased immunoreactivity of phospho-tau (Ho et al, 2003). In apolipoprotein E-deficient mice, iron challenge increased oxidative stress in folate deprived animals, but not in vitamin E. Oxidative damage can be mitigated by folate supplementation by reducing intracellular superoxide generation or scavenging hydrogen peroxide. (Shea and Rogers, 2002). In primary culture of rat cerebellar granular cells, homocysteine neurotoxicity was partially prevented by NMDA receptor antagonist. Homocysteine-induced neuronal death was effectively blocked by the combination of catalase and superoxide dismutase or catalase alone. These findings support that the homocysteine-induced neurotoxicity is based on the oxidative stress and excitotoxicity(Kim and Pae, 1996).

A number of evidence supports the roles of DNA damage and apoptosis in the pathogenesis of several neurodegenerative disorders, including cerebral ischemia (Liu et al., 1996; Won et al., 1999, 2001; Bazan, 2005). In the present study, 8-hydroxy-deoxyguanosine immunoreactivity in the CA1 region in FAD-group increased in advance of that in CDgroup, and its peak level was noted at 12 hour after ischemia/reperfusion, which was more 
pronounced in FAD-group. This result indicates that CA1 neurons in folate deficient condition are more vulnerable to ischemic DNA damage.

Endres et al. (2005) reported that cerebral lesion volumes after ischemia and 72-hour reperfusion were significantly increased by 2.1 -fold in folic acid-deficient 129 /SV wild-type mice versus controls on a normal diet, and this could not be explained by obvious differences in physiological parameters. They also reported that abasic sites, a marker of oxidative DNA damage, are significantly increased in DNA from the ischemic brains of folate-deficient 129/SV wild-type mice at early time points after MCA occlusion than control mice (Endres et al., 2005). These are supported by those of previous studies which found that folate deficiency in humans induces extensive chromosome damage, fragile site expression, micronucleus formation, and increased uracil levels in bone marrow cell DNA (Blount et al., 1997; Crott et al., 2001). The misincorporation of uracil appears to be a key event in the neurotoxicity associated with folate deficiency, because the pretreatment of culture medium with thymidine and hypoxanthine (precursors of purines) reduces neuronal cell death induced by methyl donor deficiency (Blount et al., 1997). Folate deficiency could cause the misincorporation of uracil into the DNA of proliferating cells caused by the impairment of deoxynucleoside triphosphate pools (Pogribny et al., 1997; Mol et al., 1999). In addition, homocysteine is rapidly taken up by neurons via a specific membrane transporter. Increased levels of homocysteine in cell nuclei may induce DNA strand breaks by disturbing the DNA methylation cycle (Blount et al., 1997) or may promote DNA damage accumulation in neurons by impairing DNA repair (Kruman et al., 2002).

\subsection{Folate deficiency and platelet endothelial cell adhesion molecule-1}

Adhesion and trans-endothelial migration of leucocytes play a significant roles in the pathophysiologic events in brain inflammation after stroke. Platelet endothelial cell adhesion molecule-1 (PECAM-1, CD31) is a $130-\mathrm{kDa}$ protein member of the immunoglobulin gene superfamily, which is expressed on the surface of platelets, monocytes, neutrophils, selected $\mathrm{T}$ cell subsets and on endothelial cell intercellular junctions (Newman, 1997). Expression levels of PECAM-1 differ in the type of organ tissues. It is highly expressed in kidney, lung, and trachea, while its level is at lower in brain, heart and liver. But, fibroblasts, epithelial cells, muscle, nonvascular cells or red blood cells do not express it.( Newman, 1997; Wang, 2003).

Muller et al. (1993) showed for the first time that monocytes or neutrophils treated with the specific antibodies for PECAM-1 blocked transmigration across the endothelial monolayer in vitro assay. Blocking endothelial cell junctional PECAM-1 also inhibited leukocyte transmigration, indicating that PECAM-1 molecules on both the endothelial cell as well as the leukocyte side contributed to the transmigration process. Most of PECAM in endothelium is distributed in the intercellular junctions, and $15 \%$ is on the exposed apical surface. Qing et al(2001) found that anti-PECAM-1 antibody or PECAM-Ig chimeric molecule injection blocked the T cell trafficking into the CNS in TCR transgenic mice during inflammation. Rosenblum et al.(1994) demonstrated that anti-CD31 mAb injection before the damage of endothelium in pial arteriole of mouse doubled the platelet aggregation time. Vaporciyan et al. (1993) also showed that antibody to human PECAM-1 could block in vivo accumulation of rat neutrophils into the peritoneal cavity and the alveolar compartment of the lung. These results suggest that PECAM-1 plays a key role in the transendothelial migration of leukocytes in the process of inflammation. Gumina et al.(1996) showed that 
antibodies to PECAM-1 reduce myocardial infarct size in both rat. and Murohara et al(1996) showed blockade of platelet endothelial cell adhesion molecule-1 protects against myocardial ischemia and reperfusion injury in cats.

Brain ischaemia eventually enhances local inflammatory reaction. Accumulated leucocytes adhere to endothelium, probably leading to the microvasculature occlusion (SchmidSchonbein, 1987; del Zoppo et al, 1991). Hwang et al. (2005b) demonstrated that transient ischaemia in gerbils results in a significant increase of PECAM-1 immunoreactivity in the hippocampus. PECAM-1 expression was particularly prominent in the vulnerable neurons of the hippoccampal CA1 region. PECAM-1 immunoreactivity was significantly increased by 4 days after ischaema. In addition, serum sPECAM-1 levels in ischemic group were higher than those of sham group. Zaremba and Losy (2002). reported that sPECAM-1 increases significantly in serum and in CSF in patients within $24 \mathrm{~h}$ after ischaemic stroke, compared with control group. In addition, serum and CSF sPECAM-1 levels within $24 \mathrm{~h}$ after ischaemic stroke correlated to volume of early brain CT hypodense areas, indicating the cerebral hypoperfusion. This suggests that PECAM-1 may be involved in inflammatory response mediated extent of early ischaemic brain damage. Also, sPECAM-1 levels within $24 \mathrm{~h}$ and at second week after ischaemic stroke correlated positively with neurological stroke severity, and with the degree of functional disability within $24 \mathrm{~h}$ of stroke and at second week after the incident. Therefore, initial sPECAM-1 might be of predictive value for the short-term outcome of stroke ( Zaremba and Losy, 2002b).

O'Brien et al(2003) demonstrated that PECAM-1 mediates neutrophil migration through IL1 beta stimulated endothelial cells. It has shown that hyperhomocysteinemia at moderate level activates human monocyte and induces cytokine expression including tumor necrosis alpha, IL-1 beta, IL-6, IL-8, and IL-12 (Su et al, 2005). In this experiment, PECAM-1 immunoreactivity in the CA1 region was higher in folate deficient group than in the controls. This result suggests that folate deficiency and elevated homocysteine can enhance inflammatory response in post ischemic condition through NF-kB activation. Increased gliosis in folate deficient group may be due to elevations of PECAM-1 immunoreactivity and of its protein level in vessels, inducing the transmigration of lymphocytes and neutrophils (Michiels et al., 1998; Dangerfield et al., 2002; Hwang et al., 2005b).

In summary, folate deficiency was found to induce early and significant neuronal death and gliosis in CA1 with concomitant oxidative DNA damage. These findings suggest that folate deficiency accelerate the pathological neuronal loss and inflammation that are activated after the onset of transient cerebral mild ischemia.

\section{Acknowledgements}

The author wish to thank Hwang IK, Yoo KY, Suh HW, Kim YS, Kwon DY, Kwon YG, and Won MH for excellent technical work. This work was supported by BioFoods Project in Korea Biotechnology Research Plan under the Ministry of Science and Technology of the Korea Government; Contract grant number: M10510120004-05N1012-00411; MRC program of MOST/KOSEF; R13-2005-022-01002-0; Samsung Biomedical Research Institute; CA5-220-1.

\section{References}

Allan SM, Tyrrell PJ, Rothwell NJ. (2005). Interleukin-1 and neuronal injury. Nat Rev Immunol 5:629-640. 
Baik SC, Youn HS, Chung MH, Lee WK, Cho MJ, Ko GH, Park CK, Kasai H, Rhee KH. (1996). Increased oxidative DNA damage in Helicobacter pylori-infected human gastric mucosa. Cancer Res 56: 1279-1282.

Bazan NG. (2005). Lipid signaling in neural plasticity, brain repair, and neuroprotection. Mol Neurobiol 32:89-103.

Blann AD: Endothelial cell damage and homocysteine. (1992). Atherosclerosis 94:89.

Bleich S, Degner D, Sperling W, Bönsch D, Thürauf N, Kornhuber J. (2004). Homocysteine as a neurotoxin in chronic alcoholism. Prog Neuropsychopharmacol Biol Psychiatry 28(3):453-64.

Blount BC, Mack MM, Wehr CM, MacGregor JT, Hiatt RA, Wang G, Wickramasinghe SN, Everson RB, Ames BN. (1997). Folate deficiency causes uracil misincorporation into human DNA and chromosome breakage: implications for cancer and neuronal damage. Proc Natl Acad Sci USA 94: 3290-3295.

Brouns R, De Deyn PP. (2009). The complexity of neurobiological processes in acute ischemic stroke. Clin Neurol Neurosurg 111(6):483-95.

Candelario-Jalil E, Alvarez D, Merino N, León OS. (2003). Delayed treatment with nimesulide reduces measures of oxidative stress following global ischemic brain injury in gerbils. Neurosci Res 47: 245-253.

Chang CM, Yu CC, Lu HT, Chou YF, Huang RF. (2007). Folate deprivation promotes mitochondrial oxidative decay: DNA large deletions, cytochrome c oxidase dysfunction, membrane depolarization and superoxide overproduction in rat liver. Br J Nutr 97(5):855-63.

Chern, C.L., Huang, R.F., Chen, Y.H., Cheng, J.T., Liu, T.Z., (2001). Folate deficiency-induced oxidative stress and apoptosis are mediated via homocysteine-dependent overproduction of hydrogen peroxide and enhanced activation of NF-kappa B in human Hep G2 cells. Biomed. Pharmacother 55, 434-442.

Crott JW, Mashiyama ST, Ames BN, Fenech MF. (2001). Methylenetetrahydrofolate reductase C677T polymorphism does not alter folic acid deficiency-induced uracil incorporation into primary human lymphocyte DNA in vitro. Carcinogenesis 22: 1019-1025.

Dalton, M.L., Gadson Jr., P.F., Wrenn, R.W., Rosenquist, T.H., (1997). Homocysteine signal cascade: production of phospholipids, activation of protein kinase $\mathrm{C}$, and the induction of c-fos and c-myb in smooth muscle cells. FASEB J 11, 703-711.

Dangerfield J, Larbi KY, Huang MT, Dewar A, Nourshargh S.(2002). PECAM-1 (CD31) homophilic interaction up-regulates a $6 \beta 1$ on transmigrated neutrophils in vivo and plays a functional role in the ability of a6 integrins to mediate leukocyte migration through the perivascular basement membrane. J Exp Med 196: 1201-1211.

del Zoppo GJ, Schmid-Scho“ nbein GW, Mori E, Copeland BR, Chang CM. (1991). Polymorphonuclear leukocytes occlude capillaries following middle cerebral artery occlusion and reperfusion in baboons. Stroke 22: 1276-1283.

Di Minno G Davi'G, Margaglione M, Cirillo F, Grandone E, Ciabattoni E, Catalano I, Strisciuglio P, Andria G, Patrono C, Mancini M. (1993). Abnormally high thromboxane biosynthesis in homozygous homocystinuria. Evidence for platelet involvement and Probucol-sensitive mechanism. J Clin Invest 92:1400. 
Do, K.Q., Herrling, P.L., Streit, P., Turski, W.A. and Cuenod, M. (1986). In vitro release and electrophysiological effects in situ of homocysteic acid, an endogenous N-methyl(D)-aspartic acid agonist, in the mammalian striatum. J. Neurosci 6, 2226-2234.

Durand P, Prost M, Blache D. (1996). Prothrombotic effects of folic acid deficienct diet in rat platelets and macrophages related to elevated homocysteine and decreased n-3 polyunsaturated fatty acids. Atherosclerosis 121:231-243.

Endres M, Ahmadi M, Kruman I, Biniszkiewicz D, Meisel A, Gertz K. (2005). Folate deficiency increases postischemic brain injury. Stroke 36: 321-325.

Ebbesen LS, Olesen SH, Kruhoffer M, Ingerslev J, Orntoft TF. (2006). Folate deficiency induced hyperhomocysteinemia changes the expression of thrombosis-related genes. Blood Coagul Fibrinolysis 17:293-301.

Fenech M. (2010). Folate, DNA damage and the aging brain. Mech Ageing Dev 131(4):236-41.

Fryer RH, Wilson BD, Gubler DB, Fitzgerald LA, Fodgers GM. (1993). Homocysteine, a risk factor for premature vascular disease and thrombosis, induces tissue factor activity in endothelial cells. Arterioscler Thromb 13:1327.

Giles WH, Kittner SJ, Anda RF, Croft JB, Casper ML. (1995). Serum folate and risk for ischemic stroke. First national health and nutrition examination survey epidemiologic follow-up study. Stroke 26: 1166-1170.

Gilmore TD. (2008). Rel/NF-xB transcription factors. www.nf-kb.org.

Grieve, A., Butcher, S.P., Griffiths, R., (1992). Synaptosomal plasma membrane transport of excitatory sulphur amino acid transmitter candidates: kinetic characterization and analysis of carrier specificity. J. Neurosci. Res 32, 60-68.

Gumina, R.J., J.E. Schultz, Z. Yao, D. Kenny, D.C. Warltier, P.J. Newman, and G.J. Gross. (1996). Antibody to platelet/endothelial cell adhesion molecule-1 reduces myocardial infarct size in a rat model of ischemia-reperfusion injury. Circulation 15;94(12):3327-33.

Hajjar KA. (1993). Homocysteine-induced modulation of tissue plasminogen activator binding to its endothelial cell membrane receptor. J Clin Invest 91:2873

Hankey GJ, Eikelboom JW. (2001). Homocysteine and stroke. Curr Opin Neurol 14:95-102

Harpel PC, Chang VT, Borth W. (1992). Homocysteine and other sulfhydryl compounds enhance the binding of lipoprotein(a) to fibrin: A potential biochemical link between thrombosis, atherogenesis and sulfhydryl compounds metabolism. Proc Natl Acad Sci USA 89:10193

Ho.,P.I., Ashline, D., Dhitavat, S., Ortiz, D., Collins, S.C., Shea, T.B. and Rogers, E. (2003). Folate deprivation induces neurodegeneration: roles of oxidative stress and increased homocysteine. Neurobiol. Dis. 14, 32-42.

Hwang IK, Eum WS, Yoo KY, Cho JH, Kim DW, Choi SH, Kang TC, Kwon OS, Kang JH, Choi SY, Won MH. (2005a). Copper chaperone for Cu,Zn-SOD supplement potentiates the $\mathrm{Cu}, \mathrm{Zn}-\mathrm{SOD}$ function of neuroprotective effects against ischemic neuronal damage in the gerbil hippocampus. Free Radic Biol Med 39: 392-402.

Hwang IK, Kim DW, Yoo KY, Jung BK, Song JH, Jung JY, Choi SY, Kang TC, Lee JY, Kwon YG, Won MH. (2005b). Ischemia-induced changes of platelet endothelial cell adhesion molecule-1 in the hippocampal CA1 region in gerbils. Brain Res 1048: 251-257.

Hwang IK, Yoo KY, Li H, Lee BH, Suh HW, Kwon YG, Won MH. (2007). Aquaporin 9 changes in pyramidal cells before and is expressed in astrocytes after delayed 
neuronal death in the ischemic hippocampal CA1 region of the gerbil. J Neurosci Res 85: 2470-2479.

Hwang IK, Yoo K-Y, Suh H-W, Kim YS, Kwon DY, Kwon Y-G, Yoo J-H, Won M-H. (2008). Folic Acid deficiency increases delayed neuronal death, DNA damage, platelet endothelial cell adhesion molecule-1 immunoreactivity, and gliosis in the hippocampus after transient cerebral ischemia. J Neurosci Res 86:2003-2015.

Hwang SY, Woo CW, Au-Yeung KK, Siow YL, Zhu TY, O K. (2008). Homocysteine stimulates monocyte chemoattractant protein-1 expression in the kidney via nuclear factor-kappaB activation. Am J Physiol Renal Physiol. 294(1):F236-44.

Ito, S., Provini, L. and Cherubini, E. (1991). L-homocysteic acid mediates synaptic excitation at NMDA receptors in the hippocampus. Neurosci. Lett. 124, 157-161

Jin R, Yang G, Li G. (2010). Inflammatory mechanisms in ischemic stroke: role of inflammatory cells. J Leukoc Biol. 87(5):779-89.

Kamath AF, Chauhan AK, Kisucka J, Dole VS, Loscalzo J, Handy DE, Wagner DD. (2006). Elevated levels of homocysteine compromise blood-brain barrier integrity in mice. Blood 107: 591-593.

Kang SS, Wong PW. (1996) Genetic and nongenetic factors for moderate hyperhomocyst(e)inemia. Atherosclerosis. 119(2):135-8.

Kang SS, Wong PW, Malinow MR. (1992) Hyperhomocyst(e)inemia as a risk factor for occlusive vascular disease. Annu Rev Nutr. 12:279-298.

Kanwar YS, Manaligod JR, Wong PW. (1976). Morphologic studies in a patient with homocystinuria due to 5,10-methylenetetrahydrofolate reductase deficiency. Pediatr Res 10:598-609.

Kim, J.P., Koh, J.Y. and Choi, D.W. (1987). L-homocysteate is a potent neurotoxin on cultured cortical neurons. Brain Res 437, 103-110.

Kim, W.K., Pae, Y.S. (1996). Involvement of N-methyl-D-aspartate receptor and free radical in homocysteine-mediated toxicity on rat cerebellar granule cells. Neurosci. Lett. 216, 117-120.

Kirino T, Tamura A, Sano K. (1986). A reversible type of neuronal injury following ischemia in the gerbil hippocampus. Stroke 17: 455-459.

Kirino T. (1982). Delayed neuronal death in the gerbil hippocampus following ischemia. Brain Res 239: 57-69.

Kranich O, Dringen R, Sandberg M, Hamprecht B. (1998). Utilization of cysteine and cysteine precursors for the synthesis of glutathione in astroglial cultures: preference for cysteine. Glia 22: 11-18.

Kruman II, Culmsee C, Chan SL, Kruman Y, Guo Z, Penix L, Mattson MP. (2000). Homocysteine elicits a DNA damage response in neurons that promotes apoptosis and hypersensitivity to excitotoxicity. J Neurosci 20: 6920-6926.

Kruman II, Kumaravel TS, Lohani A, Pedersen WA, Cutler RG, Kruman Y, Haughey N, Lee J, Evans M, Mattson MP. (2002). Folic acid deficiency and homocysteine impair DNA repair in hippocampal neurons and sensitize them to amyloid toxicity in experimental models of Alzheimer's disease. J Neurosci 22: 1752-1762.

Kunz A, Abe T, Hochrainer K, Shimamura M, Anrather J, Racchumi G, Zhou P, ladecola C. (2008). Nuclear factor-kappaB activation and postischemic inflammation are suppressed in CD36-null mice after middle cerebral artery occlusion. J Neurosci 28:1649-1658. 
Lehmann M, Regland B, Blennow K, Gottfries CG. (2003). Vitamin B 12 $_{2}-B_{6}$-folate treatment improves blood-brain barrier function in patients with hyperhomocysteinaemia and mild cognitive impairment. Dement Geriatr Cogn Disord 16: 145-150.

Lentz SR, Sadler JE. (1991). Inhibition of thrombomodulin surface expression and protein C activation by the thrombogenic agent homocysteine. J Clin Invest 88:1906

Lentz RS, Sobey CG, Pigeors, DJ, Bhopatkar MY, Faraci FM, Faraci FM, Malinow MR, Heistad DD. (1991). Vascular dysfunction in monkeys with diet-induced hyperhomocyst(e)inemia. J Clin Invest 98:24

Lipton SA, Kim WK, Choi YB, Kumar S, D'Emilia DM, Rayudu PV, Arnelle DR, Stamler JS. (1997). Neurotoxicity associated with dual actions of homocysteine at the $N$ methyl-D-aspartate receptor. Proc Natl Acad Sci U S A 94: 5923-5928.

Liu PK, Hsu CY, Dizdaroglu M, Floyd RA, Kow YW, Karakaya A, Rabow LE, Cui JK. (1996). Damage, repair, and mutagenesis in nuclear genes after mouse forebrain ischemiareperfusion. J Neurosci 16: 6795-6806.

Lominadze D, Roberts AM, Tyagi N, Moshal KS, Tyagi SC. (2006). Homocysteine causes cerebrovascular leakage in mice. Am J Physiol Heart Circ Physiol 290: H1206-H1213.

Michiels C, Arnould T, Remacle J. (1998). Role of PECAM-1 in the adherence of PMN to hypoxic endothelial cells. Cell Adhes Commun 5: 367-374.

Mol CD, Parikh SS, Putnam CD, Lo TP, Tainer JA. (1999). DNA repair mechanisms for the recognition and removal of damaged DNA bases. Annu Rev Biophys Biomol Struct 28: 101-128.

Muller, W.A., S.A. Weigl, X. Deng, and D.M. Phillips. (1993). PECAM-1 is required for transendothelial migration of leukocytes. J. Exp. Med 178:449-460.

Murohara, T., J.A. Delyani, S.M. Albelda, and A.M. Lefer. (1996). Blockade of platelet endothelial cell adhesion molecule-1 protects against myocardial ischemia and reperfusion injury in cats. J. Immunol. 156:3550-3557

Nedergaard M, Ransom B, Goldman SA. 2003. New roles for astrocytes: redefining the functional architecture of the brain. Trends Neurosci 26: 523-530.

Newman PJ. (1997). The Biology of PECAM-1. Journal of Clinical Investigation 99: 3-8.

Nishinaga M, Ozawa T, Shimada K. (1993). Homocysteine, a thrombogenic agent, suppresses anticoagulant heparin sulfate expression in cultured porcine aortic endothelial cells. J Clin Invest 92:1381

O'Brien CD, Lim P, Sun J, Albelda SM. (2003). PECAM-1-dependent neutrophil transmigration is independent of monolayer PECAM-1 signaling or localization. Blood. 101:2816 -2825.

Olney, J.W., Price, M.T., Salles, K.S., Labruyere, J., Ryerson, R., Mahan, K., Frierdich, GG. And Samson, L.(1987). L-homocysteic acid: an endogenous excitotoxic ligand of the NMDA receptor. Brain Res. Bull. 19, 597-602.

Pathasarathy S. (1987). Oxidation of low-density lipoprotein by thiol compounds leads to its recognition by the acetyl LDL receptor. Biochim Biophys Acta 917:337

Pogribny IP, Muskhelishvili L, Miller BJ, James SJ. (1997). Presence and consequence of uracil in preneoplastic DNA from folate/methyl-deficient rats. Carcinogenesis 18: 2071-2076.

Pullan, L. M., Olney, J.W., Price, M.T., Compton, R.P., Hood, W.F., Michel, J., Monahan, J.B. (1987). Excitatory amino acid receptor potency and subclass specificity of sulfurcontaining amino acids. J. Neurochem. 49, 1301-1307 
Pulsinelli WA, Brierley JB, Plum F. (1982). Temporal profile of neuronal damage in a model of transient forebrain ischemia. Ann Neurol 11: 491-498.

Qing Z, Sandor M, Radvany Z et al. (2001). Inhibition of antigen-specific T cell trafficking into the central nervous system via blocking PECAM1/CD31 molecule. Journal of Neuropathology and Experimental Neurology 60:798-807.

Reis, E.A., Zugno, A.I., Franzon, R., Tagliari, B., Matte, C., Lammers, M.L., Netto, C.A. and Wyse, A.T. (2002). Preteatment with vitamins E and C prevent the impairment of memory caused by homocysteine administration in rats. Metab. Brain Dis. 17, 211217.

Robert, K., Pages, C., Ledru, A., Delabar, J., Caboche, J. and Janel, N. (2005). Regulation of extracellular signal-regulated kinase by homocysteine in hippocampus. Neuroscience 133,925-935.

Rodgers GM, Kane WH. (1986). Activation of endogenous factor V by a homocysteineinduced vascular endothelial cell activator. J Clin Invest 77:1909

Rodgers GM, Conn MT. (1990). Homocysteine, an atherogenic stimulus, reduces protein C activation by arterial and venous endothelial cells. Blood 75:895

Rosenblum WI, Murata S, Nelson GH, Werner PK, Ranken R, Harmon RC. (1994). AntiCD31 delays platelet adhesion/aggregation at sites of endothelial injury in mouse cerebral arterioles. American Journal of Pathology 145: 33-36.

Saposnik G. (2011) The role of vitamin B in stroke prevention: a journey from observational studies to clinical trials and critique of the VITAmins TO Prevent Stroke (VITATOPS). Stroke. 42(3):838-42.

Schmid-Schonbein GW. (1987). Capillary plugging by granulocytes and the no-reflow phenomenon in the microcirculation. Federation Proceedings 46: 2379-2401.

Schmued LC, Hopkins K.J. (2000). Fluoro-Jade B: a high affinity fluorescent marker for the localization of neuronal degeneration. Brain Res 874: 123-130.

Schneider A, Martin-Villalba A, Weih F, Vogel J, Wirth T, Schwaninger M. (1999). NF- $B$ is activated and promotes cell death in focal cerebral ischemia. Nat Med 5:554-559.

Shea, T.B., Rogers, E. (2002). Folate quenches oxidative damage in brains of aploipoprotein E-deficient mice: augmentation by vitamin E. Brain Res Mol Brain Res. 108:1-6.

Stamler JS, Osborne JA, Jaraki M, Rabbini LE, Mullins M, Singel D, Loscalzo J. (1993). Adverse vascular effects of homocysteine are modulated by endothelium-derived relaxing factor and related oxides of nitrogen. J Clin Invest 91:308

Starkebaum G, Harlan JM. (1986). Endothelial cell injury die to dopper-catalyzed hydrogen peroxide generation form homocysteine. J Clin Invest 77:1370

Starkebaum G, Harlan JM. (1986). Endothelial cell injury die to dopper-catalyzed hydrogen peroxide generation form homocysteine. J Clim Invest 77:1370

Su SJ, Huang LW, Pai LS, Liu HW, Chang KL. (2005). Homocysteine at pathophysiologic concentrations activates human monocyte and induces cytokine expression and inhibits macrophage migration inhibitory factor expression. Nutrition 21:994-1002.

Upchurch, G.R., Welch, G.N., Fabian, A.J., Freedman, J.E., Johnson, J.E., Keaney, J.F. Jr, Loscalzo, J. (1997). Homocysteine decreases bioavail-able nitric oxide by a mechanism involving glutathione peroxidase. J. Biol, Chem. 272, 17012-17017.

Vaporciyan AA, DeLisser HM, Yan HC et al. (1993). Involvement of platelet-endothelial cell adhesion molecule-1 in neutrophil recruitment in vivo. Science 262: 1580-1582. 
Wall RT, Harlan JM, Harker LA, Striker GE. (1980). Homocysteine-induced endothelial cell injury in vitro: A model for the study of vascular injury. Thromb Res 18:113

Wang J, Dudman NPB, Wilcken DE. (1993). Effects of homocys-teine and related compounds on prostacyclin production by cultured human vascular endothelial cells. Thromb Haemost 6:1047

Wang Q, Tang XN, Yenari MA. (2007). The inflammatory response in stroke. J Neuroimmunol 184:53-68.

Wang Q, Sun AY, Simonyi A, Jensen MD, Shelat PB, Rottinghaus GE, MacDonald RS, Miller DK, Lubahn DE, Weisman GA, Sun GY. (2005). Neuroprotective mechanisms of curcumin against cerebral ischemia-induced neuronal apoptosis and behavioral deficits. J Neurosci Res 82:138-148.

Wang Y, Su X, Sorenson CM, Sheibani N. (2003). Tissue-specific distributions of alternatively spliced human PECAM-1 isoforms. American Journal of Physiology. Heart and Circulatory Physiology 284: H1008-H1017.

Won MH, Kang TC, Jeon GS, Lee JC, Kim DY, Choi EM, Lee KH, Choi CD, Chung MH, Cho SS. (1999). Immunohistochemical detection of oxidative DNA damage induced by ischemia-reperfusion insults in gerbil hippocampus in vivo. Brain Res 836: 70-78.

Won MH, Kang TC, Park SK, Jeon GS, Kim Y, Seo JH, Choi E, Chung MH, Cho SS. (2001). The alterations of $N$-methyl- $D$-aspartate receptor expressions and oxidative DNA damage in the CA1 area at the early time after ischemia-reperfusion insult. Neurosci Lett 301: 139-142.

Woo CW, Siow YL, O K. (2008). Homocysteine induces monocyte chemoattractant protein-1 expression in hepatocytes mediated via activator protein-1 activation. J Biol Chem 283(3):1282-92

Wyse, A.T., Zugno, A.I., Streck, E. L., Matte, C., Calcagnotto, T., Wannmacher, C.M. and Wajner, M. (2002). Inhibition of $\mathrm{Na}(+), \mathrm{K}(+)$-ATPase activity in hippocampus of rats subjected to acute administration of homocysteine is prevented by vitamins $\mathrm{E}$ and C treatment. Neurochem. Res 27, 1685-1689.

Yoo JH, Chung CS, Kang SS. (1998). Relation of plasma homocyst(e)ine to cerebral infarction and cerebral atherosclerosis. Stroke 29: 2478-2483.

Yoo JH, Park JE, Hong KP, Lee SH, Kim DK, Lee WR, Park SC. (1999). Moderate hyperhomocyst(e)inemia is associated with the presence of coronary artery disease and the severity of coronary atherosclerosis in Koreans. Thromb Res 94: 45-52.

Yoo JH, Park SC. (2000). Low plasma folate in combination with the $677 \mathrm{C}$ to $\mathrm{T}$ methylenetetrahydrofolate reductase polymorphism is associated with increased risk of coronary artery disease in Koreans. Thromb Res 97: 77-84.

Yoo JH, Choi GD, Kang SS. (2000). Pathogenicity of thermolabile methylenetetrahydrofolate reductase for vascular dementia. Arterioscler Thromb Vasc Biol 20:1921-1925.

Yoo JH, Lee SC. (2001). Elevated levels of plasma homocyst(e)ine and asymmetric dimethylarginine in elderly patients with stroke. Atherosclerosis 158:425-430.

Zaremba J, Losy J. (2002). sPECAM-1 in serum and CSF of acute ischaemic stroke patients. Acta Neurologica Scandinavica 106: 292-298.

Zaremba J, Losy J. (2002). Soluble platelet endothelial cell adhesion molecule-1 in ischaemic stroke patients is related to the extent of early brain damage. Central-European Journal of Immunology 27: 90-96. 


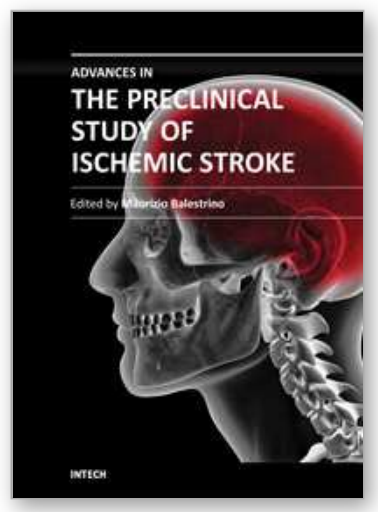

\author{
Advances in the Preclinical Study of Ischemic Stroke \\ Edited by Dr. Maurizio Balestrino
}

ISBN 978-953-51-0290-8

Hard cover, 530 pages

Publisher InTech

Published online 16, March, 2012

Published in print edition March, 2012

This book reports innovations in the preclinical study of stroke, including - novel tools and findings in animal models of stroke, - novel biochemical mechanisms through which ischemic damage may be both generated and limited, - novel pathways to neuroprotection. Although hypothermia has been so far the sole "neuroprotection" treatment that has survived the translation from preclinical to clinical studies, progress in both preclinical studies and in the design of clinical trials will hopefully provide more and better treatments for ischemic stroke. This book aims at providing the preclinical scientist with innovative knowledge and tools to investigate novel mechanisms of, and treatments for, ischemic brain damage.

\title{
How to reference
}

In order to correctly reference this scholarly work, feel free to copy and paste the following:

Jun Hyun Yoo (2012). Folate Deficiency Enhances Delayed Neuronal Death in the Hippocampus After Transient Cerebral Ischemia, Advances in the Preclinical Study of Ischemic Stroke, Dr. Maurizio Balestrino (Ed.), ISBN: 978-953-51-0290-8, InTech, Available from: http://www.intechopen.com/books/advances-in-thepreclinical-study-of-ischemic-stroke/folate-deficiency-enhances-delayed-neuronal-death-in-the-hippocampusafter-transient-cerebral-ischem

\section{INTECH}

open science | open minds

\section{InTech Europe}

University Campus STeP Ri

Slavka Krautzeka 83/A

51000 Rijeka, Croatia

Phone: +385 (51) 770447

Fax: +385 (51) 686166

www.intechopen.com

\section{InTech China}

Unit 405, Office Block, Hotel Equatorial Shanghai

No.65, Yan An Road (West), Shanghai, 200040, China

中国上海市延安西路65号上海国际贵都大饭店办公楼 405 单元

Phone: +86-21-62489820

Fax: +86-21-62489821 
(C) 2012 The Author(s). Licensee IntechOpen. This is an open access article distributed under the terms of the Creative Commons Attribution 3.0 License, which permits unrestricted use, distribution, and reproduction in any medium, provided the original work is properly cited. 